Article

\title{
One Step Synthesis of NiO Nanoparticles via Solid-State Thermal Decomposition at Low-Temperature of Novel Aqua(2,9-dimethyl-1,10-phenanthroline) $\mathrm{NiCl}_{2}$ Complex
}

Assem Barakat ${ }^{1}$, Mousa Al-Noaimi ${ }^{2}$, Mohammed Suleiman ${ }^{3}$, Abdullah S. Aldwayyan ${ }^{4}$, Belkheir Hammouti ${ }^{5}$, Taibi Ben Hadda ${ }^{6}$, Salim F. Haddad ${ }^{7}$, Ahmed Boshaala ${ }^{8}$ and Ismail Warad ${ }^{3, *}$

1 Department of Chemistry, King Saud University, P.O. Box 2455, Riyadh 11451, Saudi Arabia; E-Mail: ambarakat@ksu.edu.sa

2 Department of Chemistry, Hashemite University, Zarqa 13115, Jordan; E-Mail: manoaimi@hu.edu.jo

3 Department of Chemistry, Science College, AN-Najah National University, P.O. Box 7, Nablus, Palestine; E-Mail: suleimanshtaya@najah.edu

4 Department of Physics and Astronomy, King Saud University, P.O. Box 2455, Riyadh 11451, Saudi Arabia; E-Mail: dwayyan@ksu.edu.sa

5 Laboratoire de Chimie Appliquée et Environnement, LCAE-URAC18, Faculity of Science, University Mohammed Premier, Oujda 60000, Morocco; E-Mail: hammoutib@gmail.com

6 Lab of Chemical Material, FSO, University Mohammed Premier, Oujda 60000, Morocco; E-Mail: taibi.ben.hadda@gmail.com

7 Department of Chemistry, the University of Jordan, Amman 11942, Jordan; E-Mail: hadsa12003@yahoo.com

8 Department of Chemistry, Faculty of Science, Benghazi University, P.O. Box 1308, Benghazi 5341, Libya; E-Mail: ahmedboshaala@yahoo.co.uk

* Author to whom correspondence should be addressed; E-Mail: warad@najah.edu; Tel.: +972-9234-5113; Fax: +972-9234-5982.

Received: 23 October 2013; in revised form: 13 November 2013 / Accepted: 25 November 2013 / Published: 9 December 2013

Abstract: $\left[\mathrm{NiCl}_{2}\left(\mathrm{C}_{14} \mathrm{H}_{12} \mathrm{~N}_{2}\right)\left(\mathrm{H}_{2} \mathrm{O}\right)\right]$ complex has been synthesized from nickel chloride hexahydrate $\left(\mathrm{NiCl}_{2} \cdot 6 \mathrm{H}_{2} \mathrm{O}\right)$ and 2,9-dimethyl-1,10-phenanthroline (dmphen) as $\mathrm{N}, \mathrm{N}$-bidentate ligand. The synthesized complex was characterized by elemental analysis, infrared (IR) spectroscopy, ultraviolet-visible (UV-vis) spectroscopy and differential thermal/thermogravimetric analysis (TG/DTA). The complex was further confirmed by single crystal X-ray diffraction (XRD) as triclinic with space group P-1. The desired 
complex, subjected to thermal decomposition at low temperature of $400{ }^{\circ} \mathrm{C}$ in an open atmosphere, revealed a novel and facile synthesis of pure $\mathrm{NiO}$ nanoparticles with uniform spherical particle; the structure of the $\mathrm{NiO}$ nanoparticles product was elucidated on the basis of Fourier transform infrared (FT-IR), UV-vis spectroscopy, TG/DTA, XRD, scanning electron microscopy (SEM), energy-dispersive X-ray spectrometry (EDXS) and transmission electron microscopy (TEM).

Keywords: nickel(II) complex; thermal decomposition; 2,9-dimethyl-1,10-phenanthroline; nanoparticles

\section{Introduction}

Among transition metal oxides, nickel oxide (NiO) bulk and nano size have received considerable attention due to their wide range of applications in different fields, such as: catalysis [1-3], fuel cell electrodes and gas sensors [4-7], electrochromic films [8-10], battery cathodes [11-15] magnetic materials [16-18], and photovoltaic devices [19]. Furthermore, NiO is being studied for applications in smart windows [20], electrochemical supercapacitors [21] and dye-sensitized photocathodes [22]. Because of the quantum size and surface effects, $\mathrm{NiO}$ nanoparticles exhibit catalytic, optical, electronic, and magnetic properties that are significantly different than those of bulk-sized NiO particles [23-25].

1,10-Phenanthroline and its derivatives are well-known established $N, N$-bidentate ligands for transition metal complexation, to enrich the steric and electronic environment in such ligands different substituent function groups can be setup in their structures [22-30]. For the same reason 2,9-dimethyl-1,10-phenanthrolines and their complexes have been frequently used in the field of molecular biology and supramolecular self-assembly [22-32]. Furthermore, transition metals complexes of phenanthroline ligands are of interest to researchers because of their role in molecular scaffolding in DNA cleaving, structural studies, building blocks for the synthesis of metallo-drimers, thin films of luminescent properties, control of redox properties, analytical chemistry, and catalysis [22-32].

The starting complex and final $\mathrm{NiO}$ nanoparticles product before and after thermal decomposition were characterized on the basis of Fourier transform infrared (FT-IR), ultraviolet-visible (UV-vis) spectroscopy, differential thermal/thermogravimetric analysis (TG/DTA), X-ray diffraction (XRD), scanning electron microscopy (SEM), energy-dispersive X-ray spectrometry (EDXS) and transmission electron microscopy (TEM); additionally the complex was characterized by elemental analysis and X-ray single crystal structure.

In this work, we wish to report the synthesis and characterization of mononuclear aqua-dichloro(2,9-dimethyl-1,10-phenanthroline- $\kappa^{2} N, N$ )nickel(II) complex. Subsequently, direct thermal decomposition process of the desired complex precursor is one of the most important and straightforward strategies to access structurally elaborated and pure $\mathrm{NiO}$ nanoparticles with regular spherical particle. 


\section{Results and Discussion}

\subsection{Synthesis of the Desired Complex and NiO Nanoparticles}

The mononuclear 2,9-dimethyl-1,10-phenanthroline-nickel(II) complex was isolated in excellent yield by stirring equivalent amounts of 2,9-dimethyl-1,10-phenanthroline in distilled water with $\mathrm{NiCl}_{2} \cdot 6 \mathrm{H}_{2} \mathrm{O}$ in ethanol $[33,34]$. NiO nanoparticles were successfully synthesized through thermal decomposition of the (2,9-dimethyl-1,10-phenanthroline) $\mathrm{NiCl}_{2}$ complex precursor at $400{ }^{\circ} \mathrm{C}$. $\mathrm{NiO}$ is formed via decomposition of 2,9-dimethyl-1,10-phenanthroline organic and chloride ligands in open atmosphere to $\mathrm{NiO}$ powder product and $\mathrm{CO}_{x}, \mathrm{NO}_{x}, \mathrm{ClO}_{x}$ as expected gases bi-products. Uniform and spherical $\mathrm{NiO}$ nanoparticles with weak agglomeration were collected, as seen in Scheme 1.

Scheme 1. Synthesis of the complex and NiO nanoparticles.

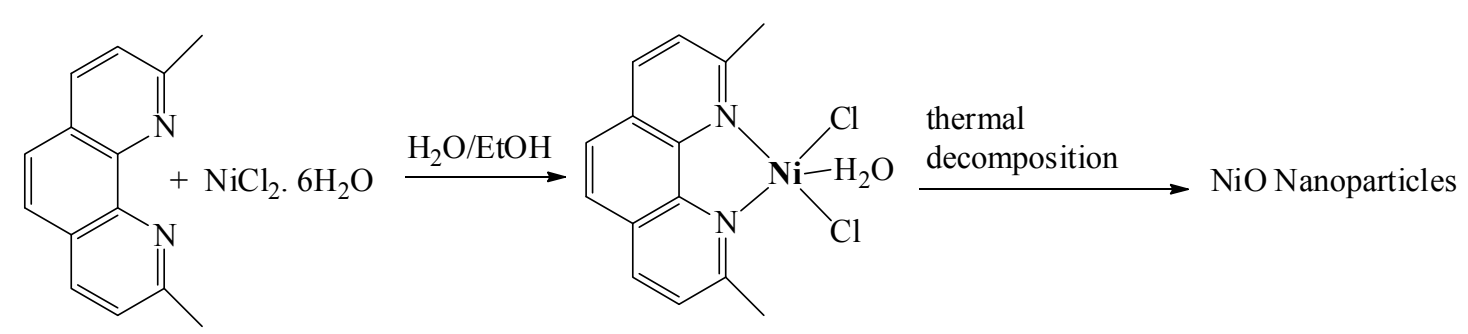

The structures of the desired complex before and after thermal decomposition to prepare the $\mathrm{NiO}$ nanoparticles product were subjected to several available physical measurements.

\subsection{Thermal Decomposition Analysis of $\mathrm{NiCl}_{2}(2,9-$ Dimethyl-1,10-phenanthroline $) \cdot \mathrm{H}_{2} \mathrm{O}$ Complex to $\mathrm{NiO}$ Nanoparticle}

The thermal properties TG/DTA of the desired complex was investigated under open atmosphere in the $0-800{ }^{\circ} \mathrm{C}$ temperature range and heating rate of $10{ }^{\circ} \mathrm{C} / \mathrm{min}$. Typical thermal TG/DTA curve is given in Figure 1.

Figure 1. TG/DTA thermal curves of the desired complex.

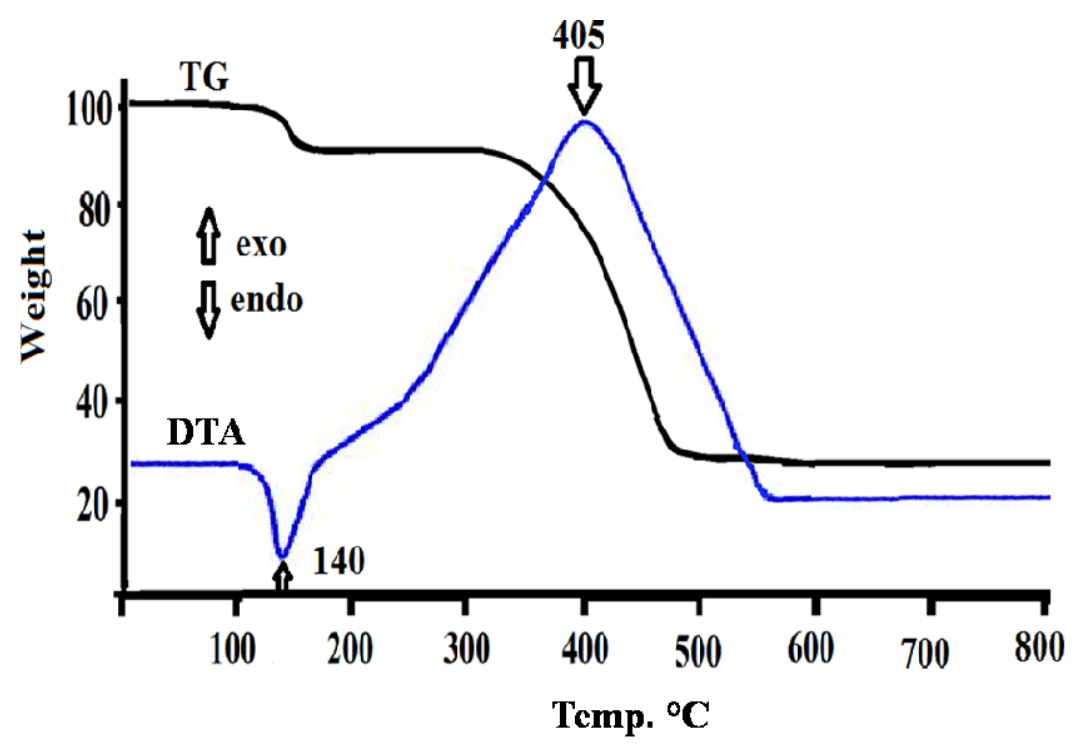


As seen from thermal curves, no uncoordinated water molecules were detected in the complex structure in the range $50-100{ }^{\circ} \mathrm{C}$. One coordinated-water molecule was recorded with weight loss $\sim 5 \%$ in the range $130-160{ }^{\circ} \mathrm{C}$ and sharp DTA endothermic signal at $\sim 140{ }^{\circ} \mathrm{C}$. Thermal decomposition study of residue complex showed no intermediate decomposition steps of the coordinated chlorides and 2,9-dimethyl-1,10-phenanthroline ligands, both ligands de-structured away from the complex to $\mathrm{CO}_{x}, \mathrm{NO}_{x}$ and $\mathrm{ClO}_{x}$ as gases by-products with one broad step decomposition at $300-500{ }^{\circ} \mathrm{C}$ and an exothermic DTA signal at $\sim 405^{\circ} \mathrm{C}$; the final main product was confirmed by IR to be $\mathrm{NiO}$, then subjected to several available physical measurements $[16,24-27,34]$.

\subsection{IR Spectral Investigation}

IR spectrum in particular showed five main sets of characteristic absorptions in the range $3410,3090,2940,530$ and $390 \mathrm{~cm}^{-1}$, which can be assigned to, coordinated- $\mathrm{H}_{2} \mathrm{O}, \mathrm{H}-\mathrm{Ph}, \mathrm{H}-\mathrm{CH}_{2}$, $\mathrm{Ni}-\mathrm{N}$ and $\mathrm{Ni}-\mathrm{Cl}$ stretching vibrations, respectively as in Figure $2 \mathrm{a}$, all bands of the of (2,9-dimethyl-1,10-phenanthroline) $\mathrm{NiCl}_{2}$ complex disappeared after thermal decomposition at $400{ }^{\circ} \mathrm{C}$ and a strong band at around $440 \mathrm{~cm}^{-1}$ is observed, as seen in Figure 2b, which was assigned to the $\mathrm{Ni}-\mathrm{O}$ stretching of the octahedral $\mathrm{NiO}_{6}$ groups in the face center cubic $\mathrm{NiO}$ structure [30-33].

Figure 2. IR-KBr disk spectra (a) desired complex; and (b) NiO nanoparticles.

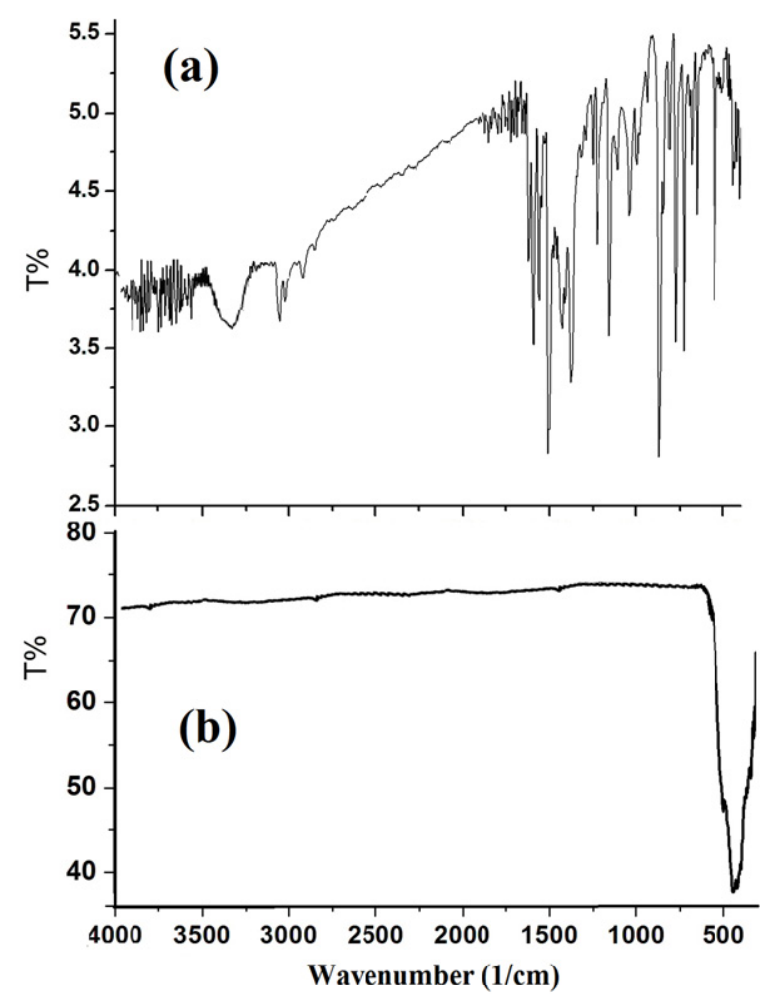

\subsection{Electronic Absorption Spectral Study}

The optical properties of the $\mathrm{NiCl}_{2}$ (2,9-dimethyl-1,10-phenanthroline) $\cdot \mathrm{H}_{2} \mathrm{O}$ complex was investigated by UV-vis spectroscopy (Figure 3a). For comparison, UV-vis spectra of the prepared $\mathrm{NiCl}_{2}$ (2,9-dimethyl-1,10-phenanthroline) $\cdot \mathrm{H}_{2} \mathrm{O}$ complex and $\mathrm{NiO}$ nanoparticles using water as solvent are also presented in Figure $3 \mathrm{~b}$. As expected, the aqueous solution of the starting complex in Figure $3 \mathrm{a}$ 
exhibits multiple absorptions in the UV-visible regions. The ligand displayed typical ligand-centered $\pi \rightarrow \pi^{*}$ transitions at 240, 280 and $304 \mathrm{~nm}$. Upon coordination with nickel ions, there are minor changes of these bands. The visible spectra of the desired complex was obtained at higher concentration $\left(10^{-4} \mathrm{M}\right)$ with the maximum absorption at 350,530 and $560 \mathrm{~nm}$ can be assigned to $d$ to $d$ electron transition or Metal to Ligand Charge Transfer (MLCT) [32-37]. It was clearly evident that the UV-vis spectrum of the $\mathrm{NiO}$ nanoparticles is quite different from that starting complex, confirming the strong band that appeared at $355 \mathrm{~nm}$ is due to $\mathrm{NiO}$ nanoparticle, not $\mathrm{Ni}$ (II) complex. This strong absorption band is attributed to the electronic transition from the valence band to the conduction band in the $\mathrm{NiO}$ semiconductor [36,37]. In addition, the UV-vis spectrum of a commercial bulk NiO powder does not show any observable absorption band [36].

Figure 3. UV-vis spectrum of the desired complex (a) and $\mathrm{NiO}$ nanoparticles dissolved in water at room temperature (b).

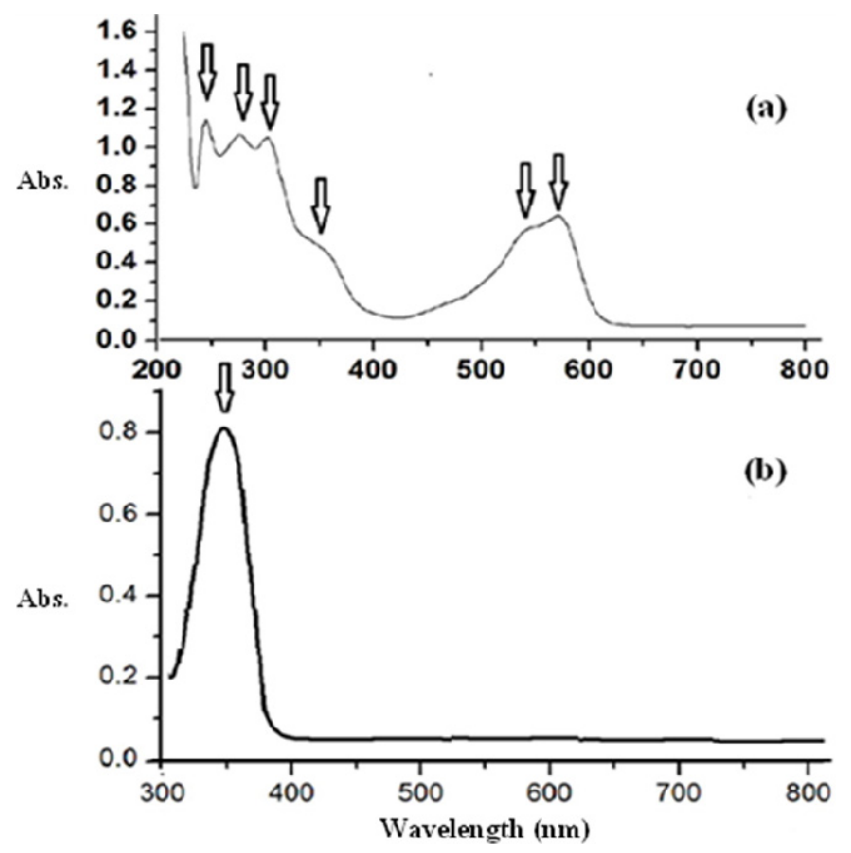

The optical band gap of $\mathrm{NiO}$ nanoparticles has been calculated from the absorption spectrum using the Tauc relation [38].

$$
(\varepsilon h v)=\mathrm{C}\left(h v-E_{\mathrm{g}}\right)^{n}
$$

Where $\mathrm{C}$ is a constant, $\varepsilon$ is molar extinction coefficient, $E_{\mathrm{g}}$ is the average band gap of the material and $n$ depends on the type of transition. For $n=1 / 2, E_{\mathrm{g}}$ in Equation (1); is direct allowed band gap. The average band gap was estimated from the intercept of linear portion of the $(\varepsilon h v)^{2} v s$. $h v$ plots, as shown in Figure 4.

The strongest absorption peak of the $\mathrm{NiO}$ prepared sample appears at around $355 \mathrm{~nm}$, which is fairly blue shifted from the absorption edge of bulk NiO nanoparticle [35,36]. The band gap energy calculated from UV-absorption is $3.96 \mathrm{eV}$. This value is higher than bulk NiO i.e., $E_{\mathrm{g}}=3.74 \mathrm{eV}$. So it is highly agreed that the synthesized $\mathrm{NiO}$ is in nano scale $[14,26]$. 
Figure 4. UV-vis band gap energy.

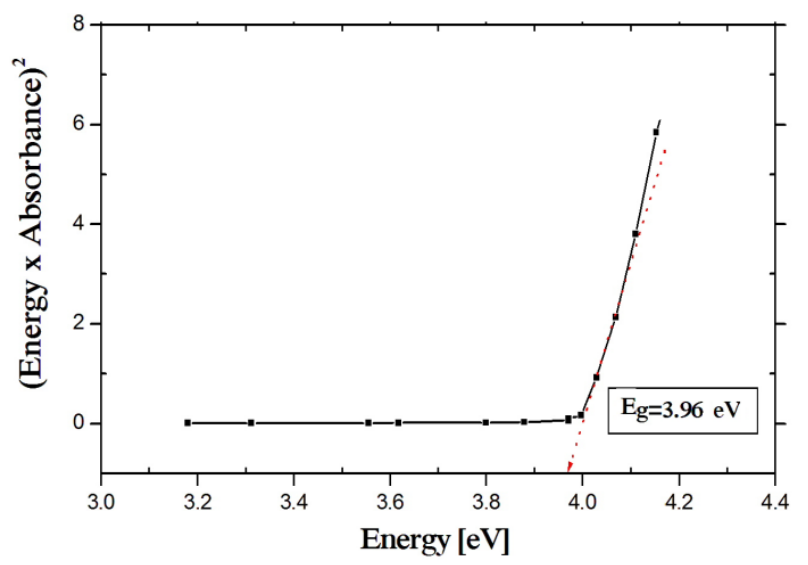

\subsection{EDX Analysis}

EDX analysis of the $\mathrm{NiCl}_{2}$ (2,9-dimethyl-1,10-phenanthroline) $\cdot \mathrm{H}_{2} \mathrm{O}$ complex and $\mathrm{NiO}$ nanoparticles product were represented in Figure 5. EDX of complex revealed several signals come from $\mathrm{Ni}, \mathrm{Cl}, \mathrm{N}$, $\mathrm{C}$ and $\mathrm{O}$, Figure 5a. After thermal decomposition process only $\mathrm{Ni}$ and $\mathrm{O}$ signals come from the $\mathrm{NiO}$ nanoparticles formation as seen in Figure $5 \mathrm{~b}$.

Figure 5. EDX spectra (a) $\mathrm{NiCl}_{2}$ (2,9-dimethyl-1,10-phenanthroline) $\cdot \mathrm{H}_{2} \mathrm{O}$ complex; and (b) $\mathrm{NiO}$ nanoparticles.

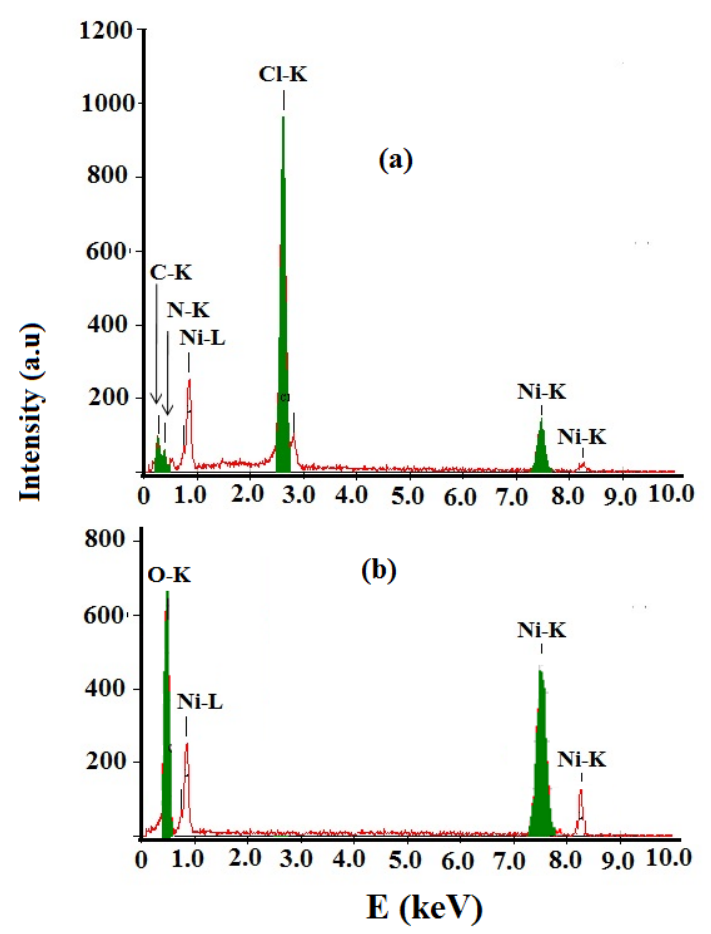

2.6. $\mathrm{X}$-ray Single Crystal of $\mathrm{NiCl}_{2}\left(2,9-D i m e t h y l-1,10\right.$-phenanthroline) $\cdot \mathrm{H}_{2} \mathrm{O}$ Complex and XRD Powder of $\mathrm{NiO}$

The molecular structure is shown in Figure 6 and selected bond distances and angles are given in the Table 1. The complex was crystallized in triclinic P-1 space group. 
Figure 6. ORTEP (Oak Ridge Thermal Ellipsoid Plot) plot of two molecular units per asymmetric unit in P-1 showing atom labelling. Thermal ellipsoids are drawn at the 50\% probability level.
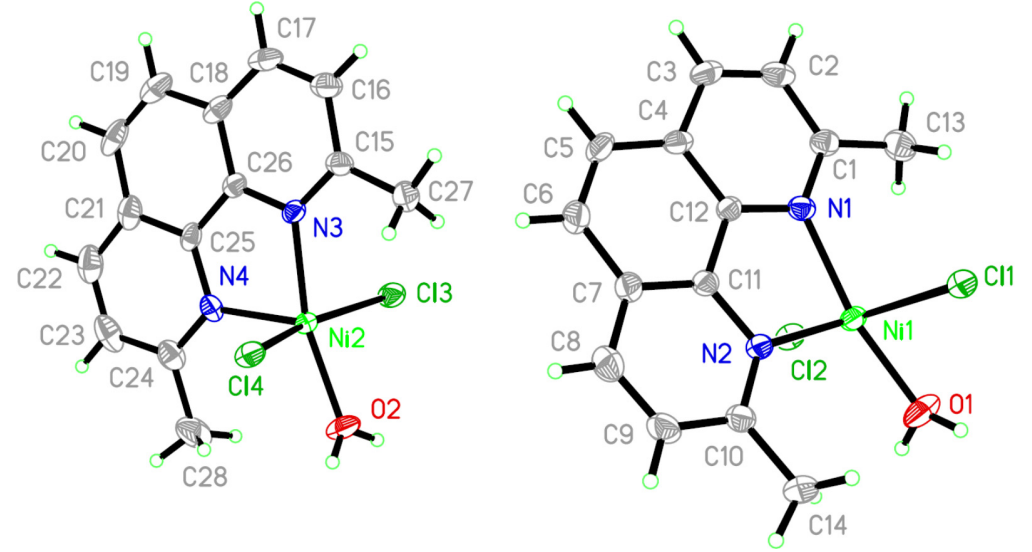

Table 1. Selected bond distances $(\AA)$ and angles $\left(^{\circ}\right)$ of the complex.

\begin{tabular}{|c|c|}
\hline Bond & Bond distances $(\AA)$ \\
\hline $\mathrm{Ni}(\mathrm{II})-\mathrm{O}(\mathrm{II})$ & $2.014(2)$ \\
\hline Ni(II)-N(III) & $2.044(2)$ \\
\hline Ni(II)-N(IV) & $2.046(3)$ \\
\hline $\mathrm{Ni}(\mathrm{II})-\mathrm{Cl}(\mathrm{IV})$ & $2.337(8)$ \\
\hline Ni(II)-Cl(III) & $2.347(2)$ \\
\hline Angles & Angles value $\left(^{\circ}\right)$ \\
\hline O(II)-Ni(II)-N(III) & 164.61(11) \\
\hline O(II)-Ni(II)-N(IV) & 113.61(11) \\
\hline N(III)-Ni(II)-N(IV) & $81.75(10)$ \\
\hline $\mathrm{O}(\mathrm{II})-\mathrm{Ni}(\mathrm{II})-\mathrm{Cl}(\mathrm{IV})$ & $87.35(6)$ \\
\hline N(III)-Ni(II)-Cl(IV) & $91.91(7)$ \\
\hline N(IV)-Ni(II)-Cl(IV) & $96.63(7)$ \\
\hline $\mathrm{O}(\mathrm{II})-\mathrm{Ni}(\mathrm{II})-\mathrm{Cl}(\mathrm{III})$ & $87.35(6)$ \\
\hline N(III)-Ni(II)-Cl(III) & $88.27(6)$ \\
\hline $\mathrm{N}(\mathrm{IV})-\mathrm{Ni}(\mathrm{II})-\mathrm{Cl}(\mathrm{III})$ & $102.71(7)$ \\
\hline $\mathrm{Cl}(\mathrm{IV})-\mathrm{Ni}(\mathrm{II})-\mathrm{Cl}(\mathrm{III})$ & $160.48(4)$ \\
\hline
\end{tabular}

The $\mathrm{Ni}$ (II) ion is five-coordinated to two $\mathrm{N}$ atoms of 2,9-dimethyl-1,10-phenanthroline and two $\mathrm{Cl}$ ions and one $\mathrm{O}$ atom of water. The overall geometry around each nickel center atom is in a slightly distorted triangular bipyramid configuration. Several $\mathrm{H}-\mathrm{O}$ and $\mathrm{H}-\mathrm{Cl}$ hydrogen-bonds were detected which may stabilized the structure of mononuclear nickel(II).

Figure 7 shows powder XRD patterns of the decomposition $\mathrm{NiCl}_{2}$ (2,9-dimethyl-1,10-phenanthroline) $\cdot \mathrm{H}_{2} \mathrm{O}$ complex product at $400{ }^{\circ} \mathrm{C}$ reveals only the diffraction peaks attributable to $\mathrm{NiO}$ with face-centered cubic phase at $2 \theta=37.40,43.45,62.95,75.40$ and 79.45, Figure 7 , which can be perfectly related to (111), (200), (220), (311) and (222) crystal planes, respectively (JCPDS card No. 73-1523). This finding confirms that at $400{ }^{\circ} \mathrm{C}$ the complex was decomposed completely to nickel oxide. No peaks of impurity were found in the XRD pattern, indicating that the nanocrystalline $\mathrm{NiO}$ obtained via this synthesis method consists of ultrapure phase. 
Figure 7. XRD patterns of $\mathrm{NiO}$ nanoparticles via complex thermal decomposed at $400{ }^{\circ} \mathrm{C}$.

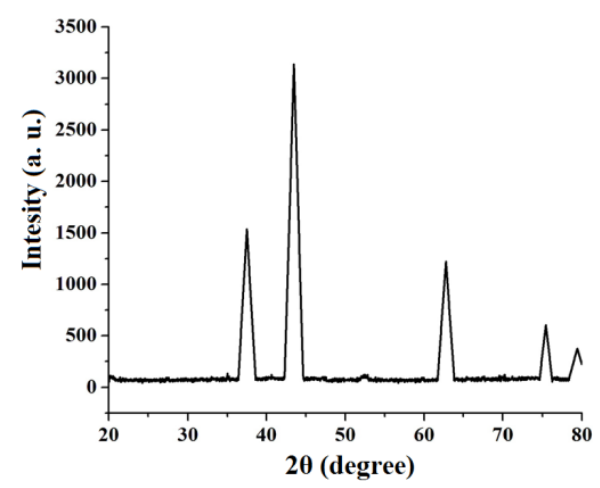

The average size of the $\mathrm{NiO}$ nanoparticles was estimated using the relative intensity peak (220) by the Debye-Scherrer equation [39], was found to be $16 \mathrm{~nm}$ and increase in sharpness of XRD peaks indicates that particles are in crystalline nature:

$$
D=(094 \lambda) /(\beta \cos \theta)
$$

Where $\lambda$ is the wavelength $(\lambda=1.542 \AA)\left(\mathrm{Cu}-\mathrm{K}_{\alpha}\right), \beta$ is the full width at half maximum (FWHM) of the line, and $\theta$ is the diffraction angle.

\subsection{SEM Measurement}

The SEM micrographs of the $\mathrm{NiCl}_{2}$ (2,9-dimethyl-1,10-phenanthroline) $\cdot \mathrm{H}_{2} \mathrm{O}$ complex and its decomposition product at $400{ }^{\circ} \mathrm{C}$ are presented in Figure 8a. We observed that the starting complex powder was made of very large block crystals in different sizes. The SEM image of the product in Figure $8 \mathrm{~b}$ clearly shows that the shape and size of particles are quite different from the precursor complex. It can be seen that the product was formed from extremely fine semi-spherical particles that were loosely aggregated. No characteristic morphology of the complex is observed, indicating the complete decomposition into the extremely fine spherical particles.

Figure 8. $\mathrm{SEM}$ micrographs (a) $\mathrm{NiCl}_{2}$ (2,9-dimethyl-1,10-phenanthroline) $\cdot \mathrm{H}_{2} \mathrm{O}$ complex and (b) $\mathrm{NiO}$ nanoparticles.

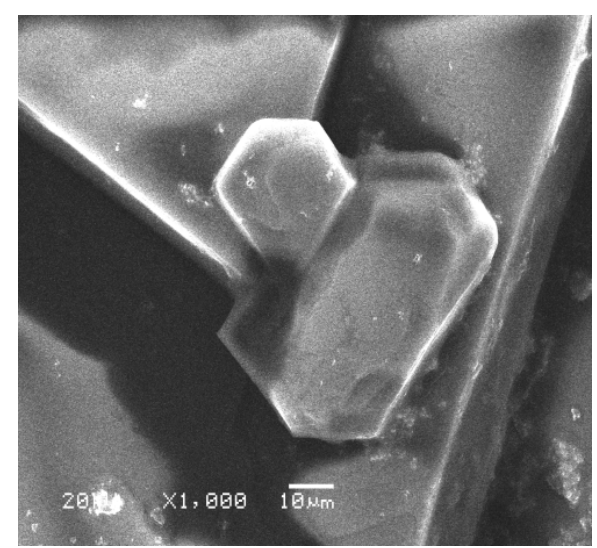

(a)

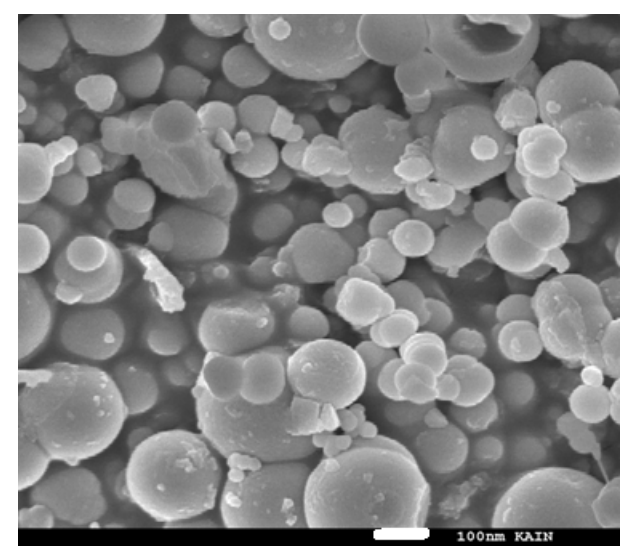

(b) 


\subsection{TEM Measurement}

The TEM images of the complex and its decomposition product at $400{ }^{\circ} \mathrm{C}$ shown on Figure 9. We observed that the TEM micrograph of the starting complex powder was made of very large block crystals in different sizes Figure 9a. Uniform NiO nanoparticles have sphere shapes with weak agglomeration Figure $9 \mathrm{~b}$ was collected after thermal decomposition of the complex. The particle sizes possess a narrow distribution in a range from 10 to $20 \mathrm{~nm}$, and the mean particle diameter is about $15 \mathrm{~nm}$. Actually, the mean particle size determined by TEM is very close to the average particle size calculated by Debye-Scherer formula from the XRD pattern.

Figure 9. TEM micrographs (a) $\mathrm{NiCl}_{2}$ (2,9-dimethyl-1,10-phenanthroline) $\cdot \mathrm{H}_{2} \mathrm{O}$ complex and (b) NiO nanoparticles.

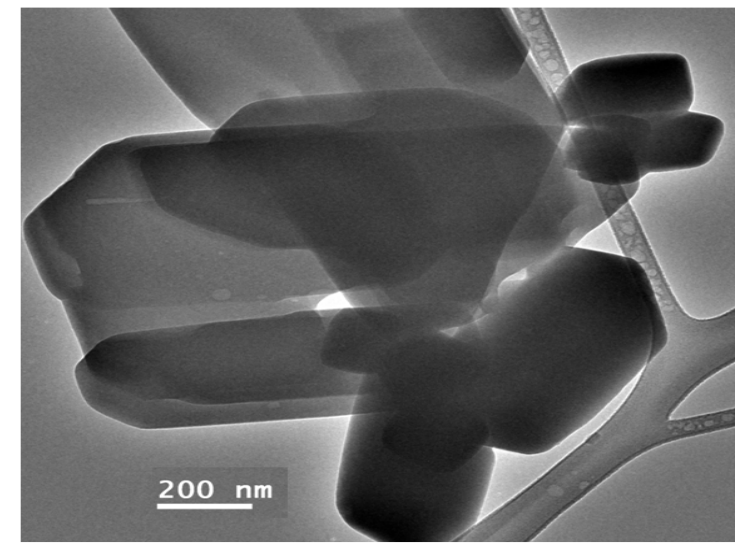

(a)

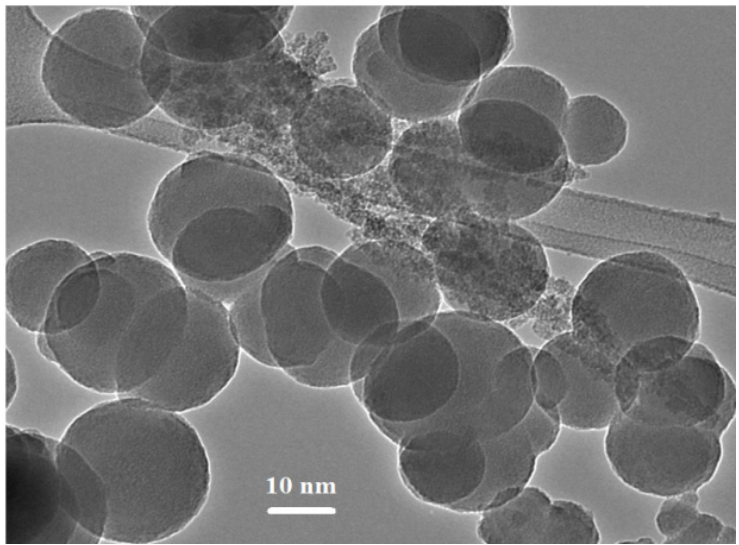

(b)

\section{Experimental Section}

\subsection{Material and Instrumentation}

2,9-Dimethyl-1,10-phenanthroline ligand and Nickel chloride hexahydrate $\mathrm{NiCl}_{2} \cdot 6 \mathrm{H}_{2} \mathrm{O}$ were purchased from Acros, Geel, Belgium and used as received. Elemental analyses were carried out on an Elementar Vario EL analyzer (Vario EL, Donaustrass, Germany) The obtained nanoparticles were examined by a Brucker D/MAX 2500 X-ray diffractometer (Brucker, Darmstad, Germany) with Cu-K radiation $(\lambda=1.54 \AA)$. The transmission electron microscopy TEM was (1001 JEOL, Maputo, Japan). The scanning electron microscopy (SEM) used a JSM-6360 ASEM (JEOL, Maputo, Japan). The IR spectra for samples were recorded using Perkin Elmer Spectrum 1000 FT-IR Spectrometer (PerkinElmer Inc., Waltham, MA, USA). Samples were measured using a TU-1901 double-beam UV-vis spectrophotometer (KFW, Haryana, India) was dispersed in water solvent.

\subsection{General Procedure for the Preparation of the Desired Complex}

A mixture of nickel chloride hexahydrate $\mathrm{NiCl}_{2} \cdot 6 \mathrm{H}_{2} \mathrm{O}$ (Acros) $(100 \mathrm{mg}, 4.10 \mathrm{mmol}$ ) in distilled water $(15 \mathrm{~mL})$ and 2,9-dimethyl-1,10-phenanthroline (Acros) (dmphen) (80 mg, $4.20 \mathrm{mmol})$ in methanol $(4 \mathrm{~mL})$ was stirred for $1 \mathrm{~h}$ at room temperature. The solution was concentrated to about $1 \mathrm{~mL}$ under reduced pressure and then added to $40 \mathrm{~mL}$ of cooled ethanol. This causes the precipitation of 
(134 mg, 92\% yield) brown powder product that was filtered, and dried, and the crystals were grown by slow diffusion of ethanol into a solution of the complex in water.

\subsection{General Procedure for the Preparation of NiO Nanoparticles}

According to the TG/DTA analysis the $0.5 \mathrm{~g}$ of $\mathrm{NiCl}_{2}$ (2,9-dimethyl-1,10-phenanthroline) $\cdot \mathrm{H}_{2} \mathrm{O}$ complex was decomposed at $400{ }^{\circ} \mathrm{C}$ temperatures for $0.5 \mathrm{~h}$ in ambient air. The decomposition products were collected for characterization.

\subsection{Supplementary Material}

Crystallographic data has been deposited with the Cambridge Crystallographic Data Centre as supplementary publication number CCDC 910435. Copies of this information may be obtained free of charge via http://www.ccdc.cam.ac.uk/conts/retrieving.html (or from the CCDC, 12 Union Road, Cambridge CB2 1EZ, UK; Fax:+44-122-3336-033; E-Mail: deposit@ccdc.cam.ac.uk).

\subsection{X-ray Structural Analyses for the Complex}

The X-ray data for complex was collected (Table 2) on Xcalibur E goniometer (Agilent Technologies, Oxford Diffraction, Oxford, UK) with enhance X-ray source and Eos CCD detector, graphite-monochromated Mo- $\mathrm{K}_{\alpha}$ radiation $(\lambda=0.71073 \AA)$ using five $\omega$-scans with a total of 350 frames at temperature of $293 \mathrm{~K}$. Data collection, cell parameters evaluation, data reduction and absorption were performed using CrysAlisPro, Agilent Technologies, Version 1.171.35.11 (release 16-05-2011 CrysAlis171 .NET, Oxford, UK). Structure determination was made using SHELXL programs (SHELXL-97, University of Gottingen, Gottingen, Germany) [40].

Table 2. Crystal data and structure refinement for the complex.

\begin{tabular}{cc}
\hline Parameters & Data \\
\hline Empirical formula & $\mathrm{C}_{14} \mathrm{H}_{14} \mathrm{C}_{12} \mathrm{~N}_{2} \mathrm{NiO}$ \\
Formula weight & $355.9 \mathrm{~g} / \mathrm{mol}$ \\
Temperature & $293.2(2) \mathrm{K}$ \\
Wavelength & $0.71073 \AA$ \\
Crystal system & Triclinic \\
Space group & $\mathrm{P}-1$ \\
& $a=7.5511(3) \AA, \alpha=106.680(5)$ \\
Unit cell dimensions & $b=11.5028(7) \AA, \beta=93.419(4)$ \\
& $c=18.9030(11) \AA, \gamma=103.448(5)$ \\
Volume & $1,515.54(14) \AA^{3}$ \\
$Z$ Formula units per unit cell & 4 \\
Density (calculated) & $1.560 \mathrm{mg} / \mathrm{m}^{3}$ \\
Absorption coefficient & $1.628 \mathrm{~mm}{ }^{-1}$ \\
$F(000)$ & $728 \mathrm{e} / \mathrm{cell}^{3}$ \\
Crystal size & $0.50 \times 0.50 \times 0.25 \mathrm{~mm}^{3}$ \\
Theta range for data collection & $2.95^{\circ}$ to $25.02^{\circ}$ \\
\hline
\end{tabular}


Table 2. Cont.

\begin{tabular}{cc}
\hline Parameters & Data \\
\hline Index ranges & $-8 \leq h \leq 8,-12 \leq k \leq 13,-22 \leq l \leq 22$ \\
Reflections collected & 10,281 \\
Independent reflections & $5,327\left[R_{\text {(int) }}=0.0283\right]$ \\
Completeness to $\theta=25.02^{\circ}$ & $99.8 \%$ \\
Absorption correction & Semi-empirical from equivalents \\
Max. and min. transmission & 0.6864 and 0.4966 \\
Refinement method & Full-matrix least-squares on $F^{2}$ \\
Data/restraints $/$ parameters & $5,327 / 8 / 379$ \\
Goodness-of-fit on $F^{2}$ & 1.062 \\
Final $R$ indices $[I>2 \sigma(I)]$ & $R 1=0.0369, w R 2=0.0756$ \\
$R$ indices (all data) & $R 1=0.0472, w R 2=0.0816$ \\
Largest difference peak and hole & 0.395 and -0.313 e $\AA^{-3}$ \\
\hline
\end{tabular}

The structure was solved by direct methods and refined by full-matrix least-squares with anisotropic temperature factor, for the non-hydrogen atoms.

\section{Conclusions}

The new $\left[\mathrm{NiCl}_{2}\left(\mathrm{C}_{14} \mathrm{H}_{12} \mathrm{~N}_{2}\right)\left(\mathrm{H}_{2} \mathrm{O}\right)\right]$ complex was subjected to thermal decomposition at low temperature of $400{ }^{\circ} \mathrm{C}$ in an open atmosphere in order to prepare uniformed spherical $\mathrm{NiO}$ nanoparticles in the range of 10-20 $\mathrm{nm}$. The structures of the complex and the $\mathrm{NiO}$ nanoparticles product were elucidated on the basis of FT-IR, UV-vis spectroscope, TG/DTA, XRD, SEM, EDX and TEM. The application of $\mathrm{NiO}$ nanoparticles is currently underway in our laboratory.

\section{Acknowledgments}

The authors extend their appreciation to the Deanship of Scientific Research at King Saud University for funding the work through the research group project Number RGP-VPP-257.

\section{Conflicts of Interest}

The authors declare no conflict of interest.

\section{References}

1. Wei, W.; Jiang, X.; Lu, L.; Yang, X.; Wang, X. Study on the catalytic effect of NiO nanoparticles on the thermal decomposition of TEGDN/NC propellant. J. Hazard. Mater. 2009, 168, 838-842.

2. Nagi, R.E.; Radwan, M.S.; El-Shall, M.; Hassan, M.A. Synthesis and characterization of nanoparticle $\mathrm{Co}_{3} \mathrm{O}_{4}, \mathrm{CuO}$ and $\mathrm{NiO}$ catalysts prepared by physical and chemical methods to minimize air pollution. Appl. Catal. A Gen. 2007, 331, 8-18.

3. Deraz, N.M.; Selim, M.M.; Ramadan, M. Processing and properties of nanocrystalline Ni and NiO catalysts. Mater. Chem. Phys. 2009, 113, 269-275. 
4. Hotovy, I.; Huran, J.; Spiess, L.; Hascik, S.; Rehacek, V. Preparation of nickel oxide thin films for gas sensors applications. Sens. Actuators B Chem. 1999, 57, 147-152.

5. Miller, E.L.; Rocheleau, R.E. Electrochemical behavior of reactively sputtered iron-doped nickel oxide. J. Electrochem. Soc. 1997, 144, 3072-3077.

6. Yang, H.X.; Dong, Q.F.; Hu, X.H. Preparation and characterization of $\mathrm{LiNiO}_{2}$ synthesized from $\mathrm{Ni}(\mathrm{OH})_{2}$ and $\mathrm{LiOH} \cdot \mathrm{H}_{2} \mathrm{O}$. J. Power Sources 1999, 79, 256-261.

7. Ichiyanagi, Y.; Wakabayashi, N.; Yamazaki, M. Magnetic properties of $\mathrm{NiO}$ nanoparticles. J. Phys. B Condens. Mater. 2003, 329-333, 862-863.

8. Li, W.Y.; Xu, L.N.; Chen, J. $\mathrm{Co}_{3} \mathrm{O}_{4}$ nanomaterials in lithium-ion batteries and gas sensors. Adv. Funct. Mater. 2005, 15, 851-857.

9. Zhang, F.B.; Zhou, Y.K.; Li, H.L. Nanocrystalline $\mathrm{NiO}$ as an electrode material for electrochemical capacitor. Mater. Chem. Phys. 2004, 83, 260-264.

10. Huang, X.H.; Tu, J.P.; Zhang, B.; Zhang, C.Q.; Li, Y.; Yuan, Y.F.; Wu, H.M.; Electrochemical properties of NiO-Ni nanocomposite as anode material for lithium ion batteries. J. Power Sources 2006, 161, 541-544.

11. Leevin, D.; Ying, J.Y. Oxidative dehydrogenation of propane by non-stoichiometric nickel molybdates. Stud. Surf. Sci. Catal. 1997, 110, 367-373.

12. Yoshio, M.; Todorov, Y.; Yamato, K.; Noguchia, H.; Itoha, J.I.; Okadab, M.; Mourib, T. Preparation of $\mathrm{Li}_{y} \mathrm{Mn}_{x} \mathrm{Ni}_{1-x} \mathrm{O}_{2}$ as a cathode for lithium-ion batteries. J. Power Sources 1998, 74, 46-53.

13. Ghosh, M.; Biswas, K.; Sundaresan, A.; Rao, C.N.R. MnO and NiO nanoparticles: Synthesis and magnetic properties. J. Mater. Chem. 2006, 16, 106-111.

14. Makhlouf, S.A.; Parker, F.T.; Spada, F.E.; Berkowitz, A.E. Magnetic anomalies in NiO nanoparticles. J. Appl. Phys. 1997, 81, 5561-5563.

15. Ahmad, T.; Ramanujachary, K.V.; Lofland, S.E.; Ganguli, A.K. Magnetic and electrochemical properties of nickel oxide nanoparticles obtained by the reverse-micellar route. Solid State Sci. 2006, 8, 425-430.

16. Borgstrom, M.; Blart, E.; Boschloo, G.; Mukhtar, E.; Hagfeldt, A.; Hammarstrom, L.; Odobel, F. Sensitized hole injection of phosphorus porphyrin into NiO: Toward new photovoltaic devices. J. Phys. Chem. B 2005, 109, 22928-22934.

17. Nathan, T.; Aziz, A.; Noor, A.F.; Prabaharan, S.R. Nanostructured NiO for electrochemical capacitors: Synthesis and electrochemical properties. J. Solid State Electrochem. 2008, 12, 1003-1009.

18. He, J.; Lindstroem, H.; Hagfeldt, A.; Lindquist, S.E. Dye-sensitized nanostructured p-type nickel oxide film as a photocathode for a solar cell. J. Phys. Chem. B 1999, 103, 8940-8943.

19. Schmidt, G. Nanoparticles: From Theory to Application; VCH: Weinheim, Germany, 2004.

20. Goldvurt, E.; Kulkarni, T.B.; Bhargava, R.N.; Taylorb, J.; Liberab, M. Size dependent efficiency in Tb doped $\mathrm{Y}_{2} \mathrm{O}_{3}$ nanocrystalline phosphor. J. Lumin. 1997, 72-74, 190-192.

21. Kalsani, V.; Schmittel, M.; Listorti, A.; Accorsi, G.; Armaroli, N. Novel phenanthroline ligands and their kinetically locked copper(I) complexes with unexpected photophysical properties. Inorg. Chem. 2006, 45, 2061-2067. 
22. Rapenne, G.; Dietrich-Buchecker, C.O.; Sauvage, J.P. Copper(I)- or Iron(II)-templated synthesis of molecular knots containing two tetrahedral or octahedral coordination sites. J. Am. Chem. Soc. 1999, 121, 994-1001.

23. Meyer, M.; Albrecht-Gary, A.M.; Dietrich-Buchecker, C.O.; Sauvage, J.P. Dicopper(I) trefoil knots: Topological and structural effects on the demetalation rates and mechanism. J. Am. Chem. Soc. 1997, 119, 4599-4607.

24. Li, G.; Shi, D.H.; Zhu, H.L.; Yan, H.; Ng, S.W. Transition metal complexes $(M=\mathrm{Cu}$, Ni and Mn) of Schiff-base ligands: Syntheses, crystal structures, and inhibitory bioactivities against urease and xanthine oxidase. Inorg. Chim. Acta 2007, 360, 2881-2889.

25. Johns, C.A.; Golzar-Hossain, G.M.; Abdul-Malik, K.M.; Zahir-Haider, S.; Rowzatur-Romman, U.K. Structural studies of $\mathrm{Ni}(\mathrm{II}), \mathrm{Zn}(\mathrm{II})$ and $\mathrm{Cd}(\mathrm{II})$ complexes with saccharinate and 2,2'-bipyridine ligands. Polyhedron 2001, 20, 721-726.

26. Ramirez-Silvaa, M.T.; Goemez-Hernaendeza, M.; Pacheco-Hernaendez, M.; Rojas-Hernaendeza, A.; Galicia, L. Spectroscopy study of 5-amino-1,10-phenanthroline. Spectrochim. Acta A Mol. Biomol. Spectrosc. 2004, 60, 781-789.

27. Binnemans, K.; Lenaerts, P.; Driesen, K.; Goerller-Walrand, C. A luminescent tris(2-thenoyltrifluoroacetonato)europium(III) complex covalently linked to a 1,10-phenanthroline-functionalised sol-gel glass. J. Mater. Chem. 2004, 14, 191-195.

28. Lenaerts, P.; Storms, A.; Mullens, J.; D’Haen, J.; Gorller-Walrand, C.; Binnemans, K.; Driesen, K. Thin films of highly luminescent lanthanide complexes covalently linked to an organic-inorganic hybrid material via 2-substituted imidazo[4,5-f]-1,10-phenanthroline groups. J. Chem. Mater. 2005, 17, 5194-5201.

29. Srinivasan, S.; Annaraj, J.; Athappan, P.J. Spectral and redox studies on mixed ligand complexes of cobalt(III) phenanthroline/bipyridyl and benzoylhydrazones, their DNA binding and antimicrobial activity. Inorg. Biochem. 2005, 99, 876-882.

30. Wellington, K.W.; Kaye, P.T.; Watkinsa, G.M. Designer ligands. Part 14. Novel Mn(II), Ni(II) and $\mathrm{Zn}$ (II) complexes of benzamide- and biphenyl-derived ligands. Arch. Org. Chem. 2008, 17, 248-264.

31. Lai, S.; Hsiao, C.; Ling, J.; Wang, W.; Peng, S.; Chen, I. Metal-metal bonding in metal-string complexes $M_{3}(\mathrm{dpa})_{4} X_{2}(M=\mathrm{Ni}, \mathrm{Co}$, dpa $=\operatorname{di}(2$-pyridyl)amido, and $X=\mathrm{Cl}, \mathrm{NCS})$ from resonance Raman and infrared spectroscopy. Chem. Phys. Lett. 2008, 456, 181-185.

32. Wang, C.; Shao, C.; Wang, L.; Zhang, L.; Li, X.; Liu, Y. Electrospinning preparation, characterization and photocatalytic properties of $\mathrm{Bi}_{2} \mathrm{O}_{3}$ nanofibers. J. Colloid Interface Sci. 2009, 333, 242-248.

33. Warad, I.; Hammouti, B.; Hadda, T.B.; Boshaala, A.; Haddad, S.F. X-ray single-crystal structure of a novel di- $\mu$-chloro-bis[chloro(2,9-dimethyl-1,10-phenanthroline)nickel(II)] complex: Synthesis, and spectral and thermal studies. Res. Chem. Intermed. 2013, 39, 4011-4020.

34. Aldwayyan, A.; Al-Jekhedab, F.; Al-Noaimi, M.; Hammouti, B.; Hadda, T.; Suleiman, M.; Warad, I. Synthesis and characterization of $\mathrm{CdO}$ nanoparticles starting from organometalic dmphen-CdI 2 complex. Int. J. Electrochem. Sci. 2013, 8, 10506-10514. 
35. Yang, P.; Yang, Y.; Zhang, C.; Yang, X.J.; Hu, H.M.; Gao, Y.; Wu, B. Synthesis, structure, and catalytic ethylene oligomerization of nickel(II) and cobalt(II) complexes with symmetrical and unsymmetrical 2,9-diaryl-1,10-phenanthroline ligands. Inorg. Chim. Acta 2009, 362, 89-96.

36. Salavati-Niasari, M.; Mohandes, F.; Davar, F.; Mazaheri, M.; Monemzadeh, M.; Yavarinia, N. Preparation of $\mathrm{NiO}$ nanoparticles from metal-organic frameworks via a solid-state decomposition route. Inorg. Chim. Acta 2009, 362, 3691-3697.

37. Salavati-Niasari, M.; Mir, N.; Davar, F. Synthesis and characterization of NiO nanoclusters via thermal decomposition. Polyhedron 2009, 28, 1111-1114.

38. Tauc, J. Optical properties and electronic structure of amorphous Ge and Si. Mater. Res. Bull. 1968, 3, 37-46.

39. Klug, H.P.; Alexander, L.E. X-ray Diffraction Procedures, 2nd ed.; Wiley: New York, NY, USA, 1964.

40. Sheldrick, G.M. SHELXL-97; University of Gottingen: Gottingen, Germany, 1997.

(C) 2013 by the authors; licensee MDPI, Basel, Switzerland. This article is an open access article distributed under the terms and conditions of the Creative Commons Attribution license (http://creativecommons.org/licenses/by/3.0/). 